\title{
ANALISIS SAMPAH LAUT (MARINE DEBRIS) DI PANTAI KUALO KOTA BENGKULU
}

\author{
Yar Johan, Person Pesona Renta, Ali Muqsit, Dewi Purnama, \\ Leni Maryani, Pinsi Hiriman, Fahri Rizky, Anggini Fuji Astuti, \\ Trisela Yunisti
}

\author{
Program Studi Ilmu Kelautan Fakultas Pertanian, Universitas Bengkulu, \\ Bengkulu, Indonesia \\ E-mail :yarjohan@unib.ac.id
}

Received Agustus 2020, Accepted September 2020

\begin{abstract}
ABSTRAK
Sampah laut (marine debris) adalah bahan sisa-sisa produk yang ditinggalkan atau dibuang ke laut oleh manusia baik dengan sengaja maupun tidak sengaja ditinggalkan di dalam lingkungan laut. Penelitian Sampah laut (marine debris) di Pantai Kualo Kota Bengkulu diharapkan dapat memberikan informasi dan data kepada mahasiswa, peneliti, pemerintah dan masyarakat umum sebagai informasi ilmiah awal tentang jenis dan bobot serta laju pertambahan sampah laut (marine debris) yang tersebar di Pantai Kualo Kota Bengkulu. Pengumpulan data dilakukan dengan teknik purposive sampling melalui observasi untuk mendapatkan komposisi sampah laut, laju pertambahan sampah laut (marine debris) dengan 3 kriteria yaitu adanya muara sungai, aktifitas masyarakat dan tumpukan sampah. Sampah laut (marine debris) di Pantai Kualo Kota Bengkulu terdapat 2 jenis yaitu sampah organik dan sampah anorganik, sampah organik didominasi oleh kayu, dan sampah anorganik didominasi oleh plastik.
\end{abstract}

Kata Kunci : Sampah Laut, Pantai, Organik, Anorganik

\section{ABSTRACT}

ANALYSIS OF MARINE DEBRISH IN KUALO BEACH, BENGKULU CITY. Marine debris is material from the remnants of the product left or thrown into the sea by human either intentionally or unintentionally dumped of in the marine environment. The research of marine debris in Kualo Beach Bengkulu city was expected to provide information and data to the students, researcher, goverment and general public as initial scientific information about types, weight, and the rate of increasing in marine debris that were scattered. The data collection was carried out by using purposive sampling technique through observation to get composition of marine debris, the rate of increasing in marine debris had three criterias namely existence of a river mouth, community activities, and pile of debris. Marine debris in Kualo Beach Bengkulu City had two types 
namely organic and inorganic debris. Organic debris was dominated by wood while inorganic debris was dominated by plastic.

Keywords : Marine Debris, Beach, Organic, Anorganic

\section{PENDAHULUAN}

Sampah adalah hasil sisa dari produk atau sesuatu yang dihasilkan dari sisa-sisa penggunaan yang manfaatnya lebih kecil dari pada produk yang digunakan oleh penggunanya, sehingga hasil dari sisa ini dibuang atau tidak digunakan kembali (Widiawati dkk., 2014). Permasalahan sampah yang tidak dapat dihindari dengan adanya peningkatan jumlah penduduk, aktivitas penduduk yang dapat meningkatkan jumlah timbulan sampah antara lain sisa makanan, kertas, kardus, plastik, tekstil, kulit, sampah kebun, kayu, kaca, logam, barang bekas rumah tangga, limbah berbahaya dan sebagainya (Taufiqurrahman, 2016).

Menurut Subekti (2017), pembuangan sampah yang sembarangan, akan berdampak langsung terhadap kebersihan dan kesehatan lingkungan sekitarnya. pada musim penghujan, sampah akan masuk ke badan air sehingga debit air sungai bertambah, kondisi ini mengakibatkan hanyutnya sampah sampah tersebut, sampah yang hanyut akan terbawa ke arah muara sungai dan akhirnya ke laut. Sampah laut (marine debris) merupakan bahan padat yang sengaja atau tidak sengaja di tinggalkan dalam laut yang memiliki dampak atau mengancam kelangsungan dan keberlanjutan hidup biota laut menurut CSIRO (2014) dalam Zulkarnaen (2017). Pencemaran pesisir dan laut semakin bertambah dengan masuknya sisa-sisa aktivitas manusia dan alam laut menerima bahanbahan yang terbawa oleh air dari daerah pertanian, limbah rumah tangga, sampah, dan bahan buangan dari kapal, tumpahan minyak lepas pantai dan masih banyak lagi bahan yang terbuang ke laut (Elyazar, 2007). Sampah laut (marine debris) merupakan ancaman langsung terhadap biota laut, habitat laut, dan kesehatan manusia, sehingga mengakibatkan kerugian aspek sosial-ekonomi yang serius, penyebaran sampah laut sangat memprihatinkan yaitu 14 miliar ton sampah dibuang setiap tahun di lautan (Hetherington et al., 2005)

Sampah masuk ke laut, terbawa oleh arus dan bergerak mengikuti arah arus laut disebut dengan sampah laut. Sampah laut (marine debris) adalah bahan sisa sisa produk yang ditinggalkan atau dibuang ke laut oleh manusia baik dengan sengaja maupun tidak sengaja, begitu juga dengan objek-objek yang dialirkan ke laut melalui sungai dan saluran pembuangan limbah rumah tangga dan industri (Yogiesti, 2010). Secara umum sampah laut merupakan setiap benda yang ada di permukaan laut, dalam laut, dan pantai sebagai dampak dari aktivitas manusia (Dwiyanto, 2011). Berbagai ukuran sampah laut (marine debris) juga bisa ditemukan pada perairan laut termasuk di pantai, mulai dari ukuran yang besar (megadebris dan macrodebris) yang keduanya dapat menimbulkan resiko yang sangat berbahaya bagi kesehatan mahluk hidup secara langsung terutama bagi hewan laut seperti ikan, penyu, dan burung-burung 
dikarenakan salah konsumsi atau karena kena jeratan, yang kesemuanya ini dapat menyebabkan pendarahan internal, bisul, penyumbatan saluran pernafasan dan pencernaan bahkan kematian bagi biota laut (Muti'ah $d k k ., 2019)$.

Dampak yang ditimbulkan oleh sampah laut dapat mengancam kelangsungan dan keberlanjutan hidup biota perairan menurut Isman (2016) dalam Bangun dkk. (2019). Sampah laut (marine debris) jika secara terus menerus meningkat maka akan berpengaruh negatif terhadap rantai makanan, perekonomian, dan kesehatan masyarakat di daerah pesisir tidak dapat dihindari. Sampah plastik dalam jumlah yang banyak dapat mempengaruhi biota yang masuk ke dalam kategori IUCN red list ataupun tidak menurut (Gall dan Thompson, 2015) dalam Assuyuti dkk., (2018). Sampah plastik diduga sebagai agen terhadap penyakit terumbu karang Harrison $d k k$. (2011). Sampah plastik dapat bertahan hingga bertahun-tahun sehingga menyebabkan pencemaran terhadap lingkungan. Sampah plastik jika dibakar akan menghasilkan gas yang akan mencemari udara dan membahayakan pernafasan manusia, dan jika sampah plastik ditimbun dalam tanah maka akan mencemari tanah, air tanah (Pribadi $d k k$., 2017).

Sampah plastik kemasan dan alat rumah tangga merupakan jenis yang sering dijumpai dalam kehidupan sehari-hari dengan sifatnya yang sulit untuk terdegradasi di alam, sampah ini dikategorikan sebagai limbah penyumbang terbesar dan menyebabkan rusaknya keseimbangan alam (Hiwari, 2019). Oleh karena itu pemakaian plastik yang jumlahnya sangat besar tentunya akan berdampak signifikan terhadap kesehatan manusia dan lingkungan karena plastik mempunyai sifat sulit terdegradasi (nonbiodegradable), plastik diperkirakan membutuhkan 100 hingga 500 tahun hingga dapat terdekomposisi (terurai) dengan sempurna, dengan demikian pemakaian plastik, baik plastik yang masih baru maupun sampah plastik haruslah menurut persyaratan yang berlaku agar tidak berbahaya terhadap kesehatan dan lingkungan.

Kota Bengkulu secara administratif terdiri dari 9 wilayah kecamatan (Bappeda Kota Bengkulu, 2013). Berdasarkan kriteria wilayah kecamatan yang memiliki ekosistem pesisir dan berbatasan langsung dengan laut, terdapat 7 Kecamatan pesisir yang ada di Kota Bengkulu, yaitu Kecamatan Muara Bangkahulu, Kecamatan Sungai Serut, Kecamatan Teluk Segara, Kecamatan Ratu Samban, Kecamatan Ratu Agung, Kecamatan Gading Cempaka dan Kecamatan Kampung Melayu (BPS Kota Bengkulu, 2019). Beberapa pantai yang diterdapat di Kota Bengkulu adalah Pantai Kualo.

Pantai Kualo memiliki daya tarik tersendiri karena berada di dekat dengan Muara Sungai Bangkahulu lokasi yang strategis terletak di sekitar wilayah Benteng Marlborought dan 15 menit dari Pantai Panjang Kota Bengkulu, karena banyaknya potensi yang ada di Pantai Kualo dan aktivitas ekowisata karena belum adanya penelitian sampah laut (marine debris) di Pantai Kualo sehingga penulis tertarik untuk melakukan penelitian tentang sampah laut (marine debris) di Pantai Kualo Kota Bengkulu. 


\section{MATERI DAN METODE}

\section{Waktu dan Tempat Penelitian}

Penelitian ini dilaksanakan pada bulan Agustus 2019 sampai Januari 2020 di Pantai Kualo Kota Bengkulu Provinsi Bengkulu.

\section{Metode Pengumpulan Data}

Pengumpulan data dilakukan dengan teknik purposive sampling melalui observasi untuk mendapatkan komposisi sampah laut, laju pertambahan sampah laut (marine debris) dengan 3 kriteria yaitu adanya muara sungai, aktifitas masyarakat seperti aktifitas ekowisata dan tumpukan sampah yang dihasilkan oleh nelayan.

\section{Prosedur Penelitian}

\section{Sampah Laut}

Data sampah diambil dengan menggunakan transek garis (line transect) berdasarkan kriteria tertentu yaitu banyaknya sampah yang dihasilkan oleh nelayan, adanya muara sungai dan aktifitas manusia seperti aktifitas ekowisata. Untuk mengetahui jenis, bobot, jumlah dan luasan sampah tersebut (Tabel 1). Pada setiap transek garis (Gambar 1) terdapat 3 transek dengan panjang masing- masing transek $5 \mathrm{~m}$, dan lebarnya $2 \mathrm{~m}, 1 \mathrm{~m}$ kerah laut dan $1 \mathrm{~m}$ kearah darat. Pengambilan sampel sampah laut (marine debris) luas area per transek. Panjang pantai yang diamati $50 \mathrm{~m}$ modifikasi Lippiatt et al. (2013). Pengambilan sampel sampah laut (marine debris) dilakukan dengan melihat luasan per transek sampah laut (marine debris). Semua sampah laut padat diambil, dibersihkan lalu dikumpulkan ke dalam karung atau kantong plastik yang berukuran besar, selanjutnya sampah disortir menurut jenis kemudian ditimbang dan diukur panjangnya sesuai lokasi yang telah ditentukan, kemudian dicatat jumlah, jenis dan bobot sampah laut padat tersebut (Walalangi, 2012).

Tabel 1. Metode pengambilan data sampah laut

\begin{tabular}{|c|c|c|c|c|}
\hline No & Parameter & Satuan & Alat/Metode & Keterangan \\
\hline \multirow[t]{3}{*}{1} & Sampah & & & \\
\hline & Jenis sampah organik & Item $/ \mathrm{m}^{2}$ & Line transek & in-situ \\
\hline & $\begin{array}{l}\text { dan anorganik } \\
\text { Berat sampah }\end{array}$ & $\mathrm{gr} / \mathrm{m}^{2}$ & Line transek & in-situ \\
\hline 2 & $\begin{array}{l}\text { Laju Pertambahan } \\
\text { potongan per item dan } \\
\text { berat sampah }\end{array}$ & $\begin{array}{c}\text { Item } / \mathrm{m}^{2} / \text { hari } \\
\mathrm{gr} / \mathrm{m}^{2} / \text { hari }\end{array}$ & Line transek & in-situ \\
\hline
\end{tabular}




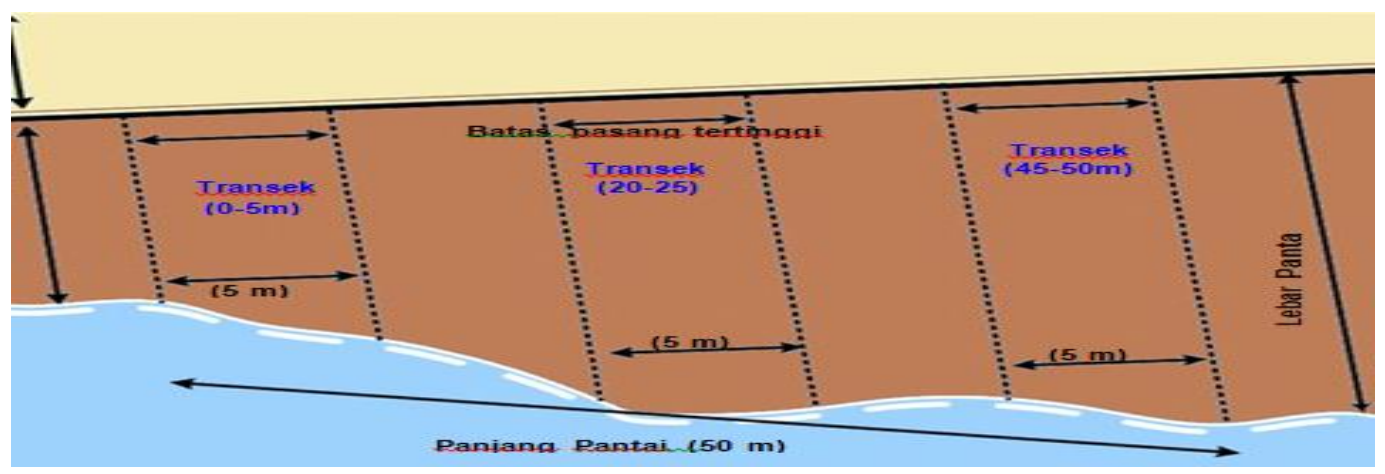

Gambar 1. Teknik pengambilan sampel sampah laut (marine debris) (Modifikasi Walalangi, 2012).

\section{Data Pertambahan Sampah Laut (Marine Debris)}

Teknik pengambilan sampel pertambahan sampah dengan titik pengamatan pada Stasiun1, Stasiun 2, dan Stasiun 3. Stasiun pengambilan sampah di tepi pantai dengan transek garis (line transect). Setiap transek garis terdiri dari 3 transek dengan panjang masing- masing transek $5 \mathrm{~m}$, memiliki lebar $2 \mathrm{~m}$, dimana $1 \mathrm{~m}$ kerah laut dan $1 \mathrm{~m}$ kearah darat. Waktu pengamatan dilakukan selama 13 hari, dimulai pada tanggal 7-19 Agustus 2019 pengambilan sampel dilakukan setiap 2 hari sekali. Sampah laut yang terdeposit diambil kemudian dimasukan kedalam karung/plastik lalu dibawa pulang dan dipilah, dicatat jenis, bobot dan ukuran sampah laut padat tersebut (Eriksson et al., 2013), pengamatan langsung di lapangan pada saat pengambilan sampel sampah laut pada tiap-tiap transek, panjang transek garis $50 \mathrm{~m}$.

\section{Analisis Data}

\section{Analisis Jenis dan Bobot}

Analisis jenis dan bobot diambil dari sampah yang telah diamati seperti jumlah potongan, berat, komposisi dan kepadatan sampah padat di Pantai Kualo Kota Bengkulu, dan dipisahkan sesuai jenis organik, anorganik menurut Tangdesu (2018), kemudian dipisahkan lagi sesuai kategorinya plastik, karet, logam, kaca kayu dan turunannya menurut Djaguna dkk. (2019)

\section{Kepadatan Potongan Sampah}

Analisis kepadatan dan kepadatan relatif sampah padat mengacu pada Coe dan Rogers (1997).

Kepadatan (jumlah potongan sampah)

$$
=\frac{\text { Jumlah potongan per item sampah dalam tiap kategori (item) }}{\text { Luas area }\left(m^{2}\right)}
$$


Kepadatan (berat sampah)

$$
=\frac{\text { Berat potongan per item sampah dalam tiap kategori }(\mathrm{gr})}{\text { Luas area }\left(\mathrm{m}^{2}\right)}
$$

Kepadatan relatif (jumlah potongan sampah)

$$
=\frac{\text { Jumlah potongan per item sampah dalam tiap kategori (item) }}{\text { Jumlah total potongan per item sampah semua kategori (item) }} \times 100 \%
$$

Kepadatan relatif (berat sampah)

$$
=\frac{\text { Berat potongan per item sampah dalam tiap kategori }(\mathrm{gr})}{\text { Jumlah total berat potongan per item sampah semua kategori (gr) }} \times 100 \%
$$

\section{HASIL DAN PEMBAHASAN}

\section{Jenis Sampah Laut (Marine Debris) di Pantai Kualo}

Berdasarkan hasil pengamatan terdapat 2 jenis sampah laut (marine debris) yaitu sampah organik dan sampah anorganik, sampah organik terdiri dari kayu dan turunannya sampah anorganik yang ditemukan yaitu plastik, karet, pipet, kaca, kain, dan logam.

Tabel 2. Jenis-jenis sampah laut (marine debris)

\begin{tabular}{lccc}
\hline \multicolumn{1}{c}{ Jenis } & Stasiun 1 & Stasiun 2 & Stasiun 3 \\
\hline $\begin{array}{l}\text { Organik } \\
\text { Kayu dan turunanya }\end{array}$ & + & & \\
$\begin{array}{l}\text { Anorganik } \\
\text { Plastik }\end{array}$ & + & + & + \\
Karet & + & + & + \\
Kaca & + & - & - \\
Kain & - & + & + \\
Logam & - & - & + \\
dan lain-lainya & - & + & + \\
\hline
\end{tabular}

Berdasarkan hasil (Tabel 2) yang didapatkan pada Stasiun 1 jenis sampah organik yang ditemukan adalah kayu dan turunanya diduga pada Stasiun 1 yang terletak di dekat muara sungai, sehingga sampah yang berasal dari hulu sungai terbawa ke hilir dan bermuara kelaut, pada sampah anorganik yang didominasi adalah sampah plastik, diduga sampah ini berasal dari buangan manusia yang sengaja atau tidak sengaja dibuang atau di tinggalkan di dalam lingkungan laut. (Subekti, 2017) yang menyatakan pada musim penghujan, sampah akan masuk ke badan air sehingga debit air sungai bertambah, kondisi ini mengakibatkan hanyutnya sampah tersebut, sampah yang hanyut akan terbawa ke arah 
muara sungai dan akhirnya kelaut. Persentase jenis sampah laut (marine debris) organik dan anorganik dapat dilihat pada Tabel 3 dan Tabel 4.

Tabel 3. Persentase sampah laut berdasarkan jumlah potongan per item

\begin{tabular}{lcc}
\hline Jenis sampah laut & & Persentase (\%) \\
\hline Sampah laut organik & 44,33 & 38,78 \\
Sampah laut & 69,99 & 61,22 \\
anorganik & 114,33 & \\
\hline Jumlah total & & \\
\hline
\end{tabular}

Tabel 4. Persentase sampah laut berdasarkan berat potongan per item

\begin{tabular}{lcc}
\hline Jenis sampah laut & & Persentase (\%) \\
\hline Sampah laut organik & 800,80 & 37,94 \\
Sampah laut & & \\
anorganik & 1310,04 & 62,06 \\
\hline Jumlah Total & 2110,84 & \\
\hline
\end{tabular}

Berdasarkan hasil perhitungan persentase jenis sampah laut (marine debris) organik dan anorganik menurut jumlah potongan per item pada keseluruhan stasiun yaitu Stasiun 1, Stasiun 2, Stasiun 3 didapatkan nilai persentase sampah laut organik sebesar 38,78 \% dan sampah laut (marine debris) anorganik memiliki nilai persentase sebesar 61,22\% (Tabel 3).

Berat sampah laut (marine debris) organik dan anorganik pada keseluruhan Stasiun didapatkan nilai persentase sampah laut organik sebesar $37,94 \%$ dan sampah laut (marine debris) anorganik dengan persentase nilai sebesar 62,06\% (Tabel 4). Berdasarkan persentase jumlah potongan dan berat potongan per item sampah laut (marine debris) pada lokasi penelitian menunjukkan bahwa sampah laut (marine debris) anorganik yang lebih banyak di bandingkan sampah laut (marine debris) organik. Hal ini di duga sampah organik tersebut berasal dari sungai sehingga menumpuk di muara sungai dan aktivitas manusia di dekat lokasi penelitian. NOAA (2016) menyatakan bahwa hasil penelitian mengenai sampah laut yang terdapat di seluruh perairan di dunia, jenis sampah plastik merupakan jenis yang paling umum dan banyak dijumpai serta yang paling berisiko memberikan dampak yang cukup serius bagi organisme laut. Seperti yang dikemukan oleh Muharlis (2014), sampah laut plastik dianggap memiliki potensi terbesar untuk mengubah lingkungan, berdampak buruk pada biota dan manusia, karena mengapung di permukaan, banyak diangkut oleh arus laut, bertahan dalam lingkungan selama bertahun-tahun, dan tidak mudah dicerna bila dikonsumsi. 


\section{Jumlah Rata-Rata Potongan Per Item dan Berat Sampah Laut (Marine Debris)}

Jumlah rata-rata potongan per item dapat di lihat pada Gambar 2.

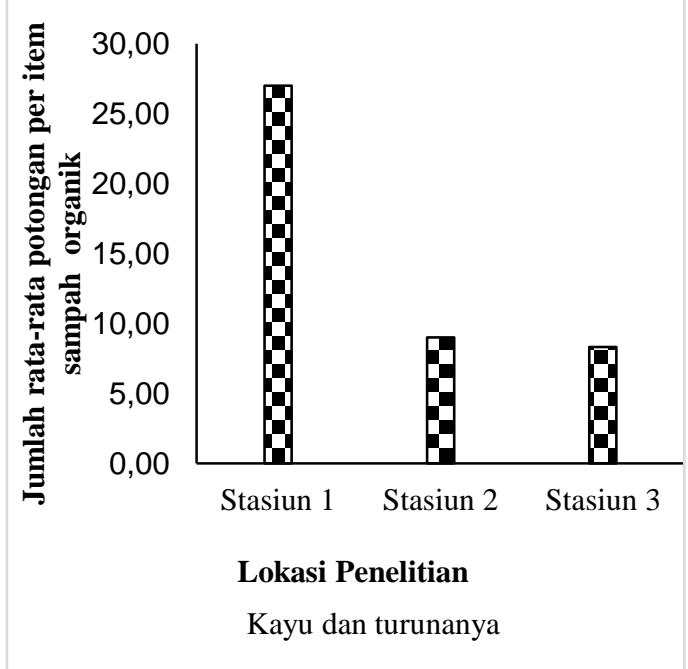

(a) Organik

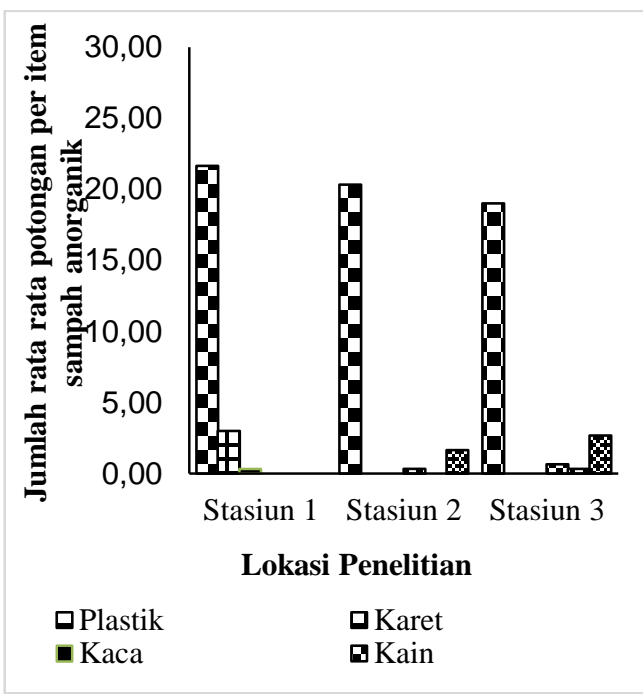

(b) Anorganik

Gambar 2. Rata-rata potongan per item sampah laut (marine debris)

Berdasarkan hasil penelitian didapatkan jumlah rata-rata item sampah laut (marine debris) organik pada lokasi penelitian (Gambar 2) dengan nilai tertinggi yaitu kayu dan turunanya 27,00 item dan nilai terendah 8,33 item pada Stasiun 3. Besar jumlah item sampah laut (marine debris) didasarkan pada penelitian yang tertinggi pada Stasiun 1 yaitu kayu dan turunanya hal ini dikarenakan Stasiun 1 terletak didekat muara sungai diduga kayu kayu dan turunanya yang berasal dari alam dan aktifitas manusia yang menebang pohon secara sembarangan, ketika musim penghujan, sampah akan masuk ke badan air debit air sungai bertambah, sehingga hanyutnya sampah tersebut, sampah yang hanyut akan terbawa ke arah muara sungai dan berakhir kelaut. Pada sampah anorganik didominasi oleh sampah plastik pada Stasiun 1, Stasiun 2 dan Stasiun 3 dengan nilai tertinggi 21,66 item dan nilai terendah 0,33 item, hal ini diduga sampah yang dibuang dari aktifitas rumah tangga dan sampah dari darat melalui aliran sungai dimana perilaku masyarakat yang menjadikan sungai sebagai tempat pembuangan sampah, sehingga sampah-sampah tersebut akan berdampak kelaut.

Pencemaran Pesisir dan laut semakin bertambah dengan masuknya sisa-sisa aktifitas manusia selain masukkan dari alam, sampah masuk ke laut, terbawa oleh arus dan bergerak mengikuti arah arus laut disebut dengan sampah laut yang ditinggalkan atau dibuang ke laut oleh manusia baik dengan sengaja maupun tidak sengaja, begitu juga dengan objekobjek yang dialirkan kelaut melalui sungai dan saluran pembuangan limbah rumah tangga dan industry (NOAA, 2013). 


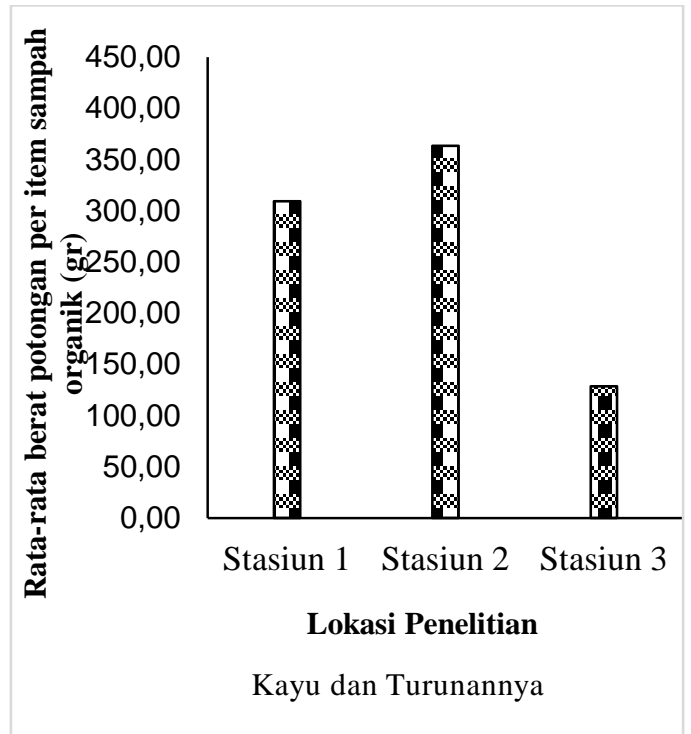

(a) Organik

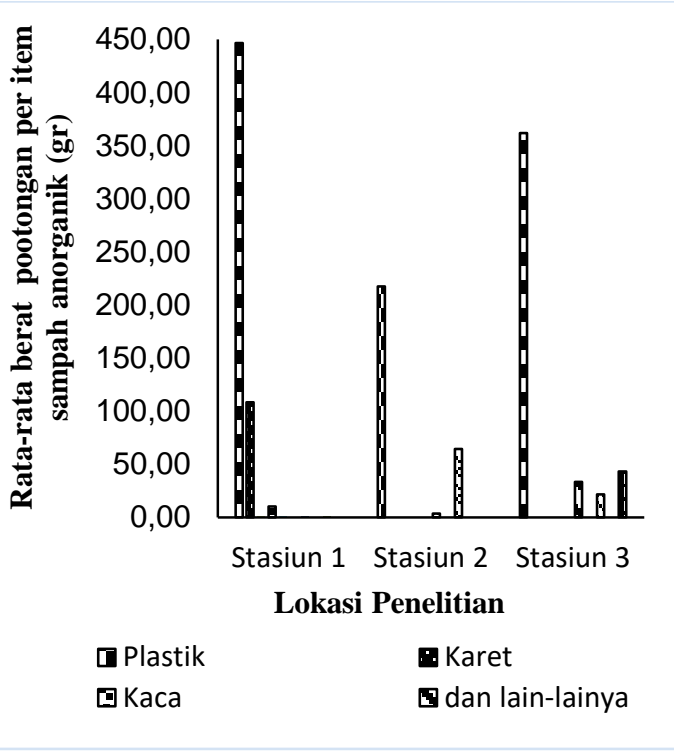

(b) Anorganik

Gambar 3. Rata-rata berat potongan per item sampah laut

Berdasarkan hasil yang diperoleh berat potongan per item sampah laut (marine debris) pada Stasiun 2 sampah organik yaitu kayu dan turunanya dengan nilai teringgi 363,34 gr dan nilai terendah adalah 128,38 gr, berat sampah anorganik disetiap Stasiun yang mendominasi adalah plastik dengan nilai tertinggi 446,41 dan nilai terendah 3,33 gr (Gambar 3) hal ini dikarenakan sampah yang dihasilkan dari alam dan aktifitas manusia yang membuang sampah secara sembarangan dan salah satunya aktifitas manusia yang berada di hulu sungai sehingga sampah yang dihasilkan akan masuk ke badan air kemudian terbawa ke hilir dan akhirnya bermuara ke laut.

Menurut (Asia dan Arifin, 2017) sumber sampah yang menjadi indikasi produksi sampah adalah dari aktivitas rumah tangga, ekowisatawan, nelayan, pedagang, industri, dan transportasi, jenis sampah seperti plastik kemasan dan alat rumah tangga merupakan jenis yang sering dijumpai dalam kehidupan sehari-hari dengan sifatnya yang sulit untuk terdegradasi di alam, sampah ini dikategorikan sebagai limbah penyumbang terbesar dan menyebabkan rusaknya keseimbangan alam.

\section{Komposisi dan Kepadatan Sampah Laut (Marine Debris)}

Berdasarkan pengamatan sampah laut (marine debris) di lokasi penelitian terdapat 2 komposisi yaitu sampah organik dan sampah anorganik, sampah organik terdiri dari kayu dan turunanya, yang terdeposit di pesisir, sampah ini berasal dari muara sungai, dan aktifitas masyarakat yang berada di hulu sungai, sehingga banyak menimbulkan sampah dan kebiasaan masyarakat yang cendrung membuang sampah sembarangan, sehingga yang berasal dari darat semuanya akan bermuara ke laut dan akan terdeposit ke pesisir. 
Jenis sampah yang terdeposit di sepanjang Pantai Kualo Kota Bengkulu adalah buangan sampah domestik, hal ini terlihat dari jenis sampah organik yang padat dan ringan sehingga terjadi penumpukan sampah di beberapa titik, hal ini tidak jauh berbeda dengan (Nursruwening $d k k ., 2015)$ sampah domestik merupakan sampah yang tidak dipakai dari sumber hasil aktifitas manusia maupun alam yang belum memiliki nilai ekonomis yang berasal dari rumah tangga.

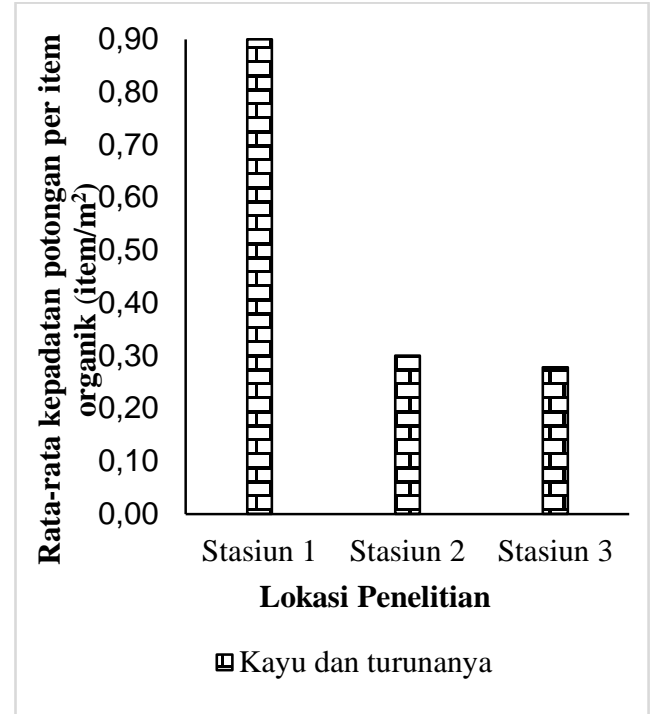

(a) Organik

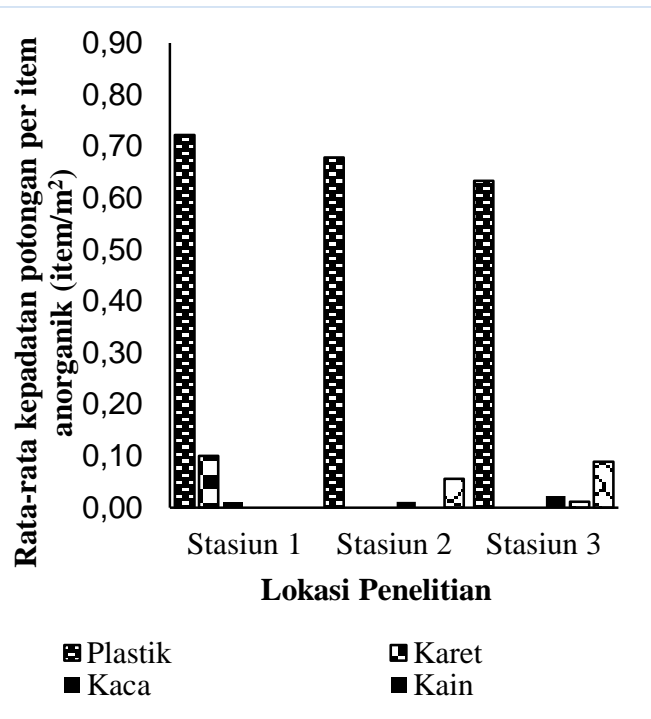

(b) Anorganik

Gambar 4.Rata-rata kepadatan menurut jumlah potongan per item

Berdasarkan hasil penelitian rata-rata kepadatan potongan per item sampah laut (marine debris) organik dan turunanya pada lokasi penelitian (Gambar 4) di dapatakan nilai tertinggi pada Stasiun 1 dengan nilai 0,90 (item $/ \mathrm{m}^{2}$ ) dan nilai terendah 0,28 (item $/ \mathrm{m}^{2}$ ) dan untuk lebih jelas bisa dilihat pada (Lampiran 1), dimana pada lokasi penelitian terdapat muara sungai diduga sampah kayu dan turunanya bukan hanya berasal dari masyarakat setempat akan tetapi aktifitas manusia yang berada di hulu sungai yang menyebabkan sampah terbawa oleh aliran air ke hilir sungai. Kepadatan sampah anorganik yang didominasi oleh jenis plastik dengan nilai tertinggi 0,72 (item $/ \mathrm{m}^{2}$ ) dan nilai terendah 0,01 (item $/ \mathrm{m}^{2}$ ) hal ini diduga adanya muara sungai, aktifitas ekowisata dan nelayan, sehingga menyebabkan banyaknya tumpukan sampah. Sampah laut didefinisikan oleh NOAA (2013) sebagai benda padat yang diproduksi atau diproses oleh manusia, secara langsung maupun tidak langsung dibuang ke dalam lingkungan perairan.

Sampah merupakan isu penting dalam masalah lingkungan perkotaan yang dihadapi sejalan dengan perkembangan jumlah penduduk dan peningkatan aktivitas pembangunan. Ada beberapa hal yang mempengaruhi yaitu sampah dari masyarakat yang tinggal dan melakukan aktivitas di wilayah pesisir, sampah kiriman dari wilayah daratan atas yang 
mengalir dari sungai atau selokan yang bermuara ke pesisir (Renwarin et al., 2002).

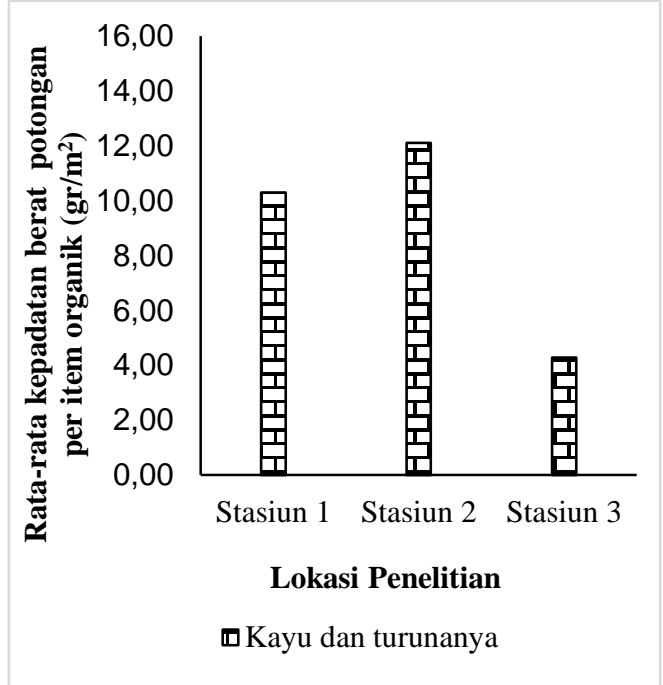

(a) Organik

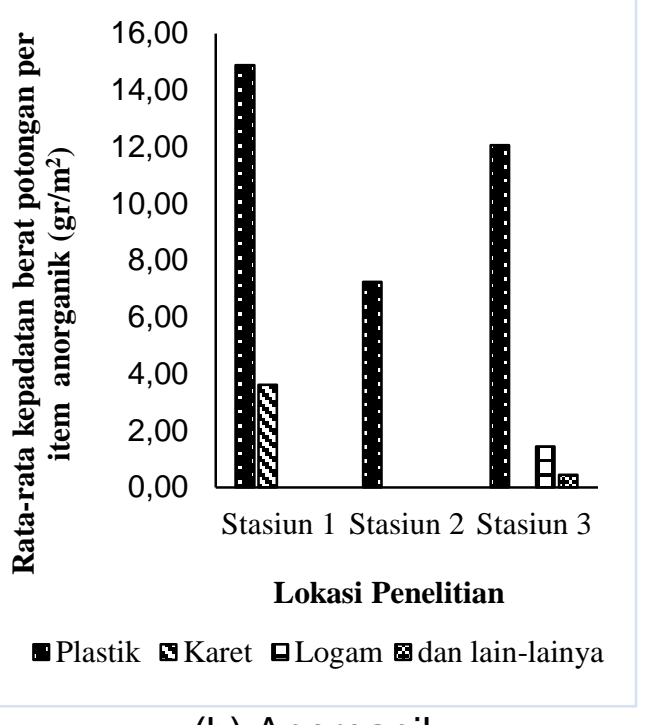

(b) Anorganik

Gambar 5. Rata-rata kepadatan berat potongan per item sampah laut

Berdasarkan penelitian rata-rata kepadatan berat potongan per item sampah laut (marine debris) organik dengan berat potongan tertinggi pada Stasiun 2 yang didominasi kayu dan turunnya dengan nilai $12,11\left(\mathrm{gr} / \mathrm{m}^{2}\right)$ dan sampah anorganik tertinggi pada stasiun 1 yang didominasi oleh sampah plastik, dengan nilai tertinggi $14,88\left(\mathrm{gr} / \mathrm{m}^{2}\right)$ dari kedua jenis sampah tersebut berat sampah tertinggi didominasi oleh sampah anorganik, sampah ini diduga berasal dari muara sungai, aktifitas ekowisata, dan nelayan, sehingga berpotensi menghasilkan sampah, terutama sampah plastik (Walalangi, 2012) yang menyatakan bahwa kepadatan berat potongan yang tertinggi yaitu sampah anorganik seperti plastik, kaca, kain, karet, kertas dan stylofrom.

Sampah di daerah pesisir merupakan salah satu permasalahan kompleks yang dihadapi oleh suatu daerah yang berada dekat dengan pantai atau pesisir yang memiliki beberapa sungai yang bermuara ke laut (Dewi et al., 2015).

\section{Kepadatan Relatif Sampah Laut (Marine Debris)}

Kepadatan relatif merupakan presentase banyaknya jumlah sampah. Berdasarkan hasil pengamatan data kepadatan relatif terbagi menjadi 2 kategori yaitu sampah organik dan sampah anorganik, sampah organik terdiri dari kayu dan turunanya pada sampah anorganik terdiri dari plastik, karet, kaca, logam, kain, dan lain-lainnya. Sampah organik berdasarkan jumlah potongan per item didominasi oleh kayu dan turunanya dan sampah anorganik didominasi oleh plastik. 


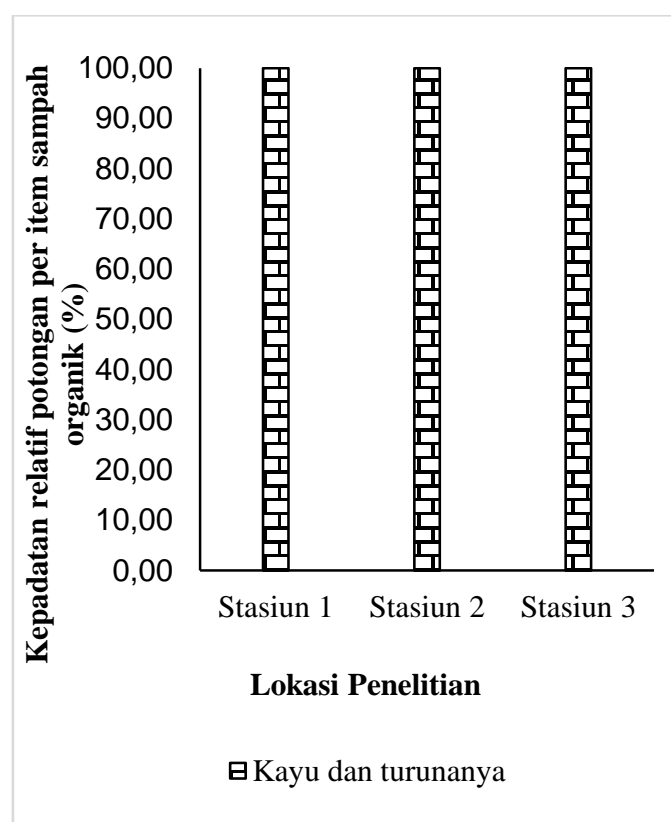

(a) Organik

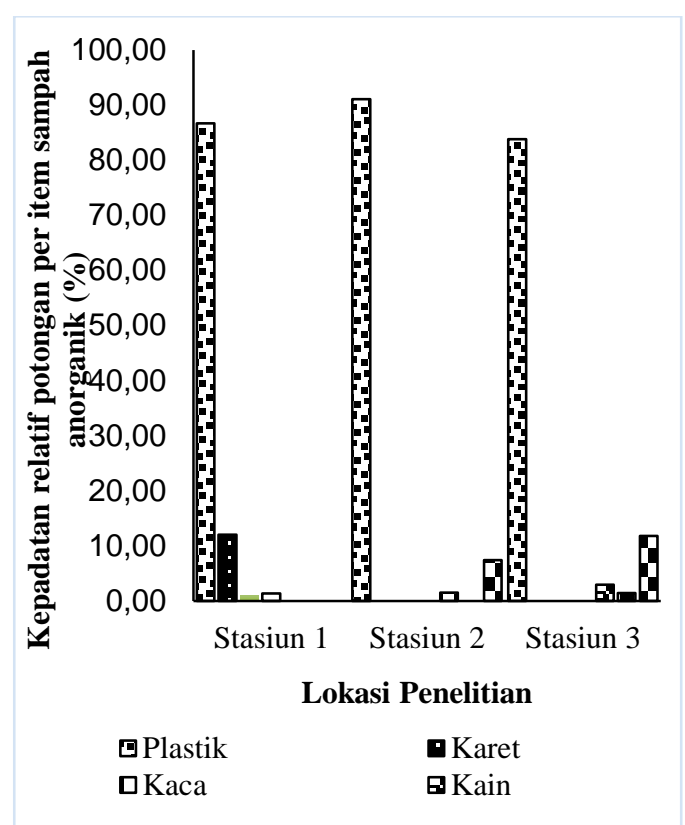

(b) Anorganik

Gambar 6. Kepadatan relatif menurut potongan per item sampah laut

Berdasarkan hasil penelitian (Gambar 6) yang telah dilakukan mengenai kepadatan relatif jumlah potongan per item sampah laut (marine debris) organik terdiri dari kayu dan turunanya dimana presentase kayu dan turunanya $100 \%$ yang didapatkan dilokasi penelitian pada sampah anorganik presentase tertinggi plastik $86,66 \%$ dan terendah $1,33 \%$. Besarnya presentase jumlah potongan per item sampah di pengaruhi oleh beberapa faktor yang berasal dari masyarakat setempat serta dari alam dan aktifitas manusia yang ada di hulu sungai, sehingga sampah yang dihasilkan dari aktifitas tersebut akan terbawa ke hilir dan akhirnya bermuara kelaut.

Menurut (Hermawan, 2017) kepadatan relatif menurut jumlah potongan sampah laut yang tersebar di sepanjang pesisir barat Pulau Selayar, didominasi oleh sampah kayu yang berukuran besar hal ini dikarenakan Stasiun yang berdektan dengan muara sungai yang landai dan sampah terbawa arus terdeposit di tepi pantai atau daerah intertidal. Persentase kepadatan sampah anorganik di ekosistem mangrove pantai Talawaan Bajo adalah sampah jenis plasik yang tertinggi (81,48 \%), sampah jenis plastik, karet, logam, kaca, serta kayu dan turunan. Sampah plastik merupakan sampah yang paling banyak di temukan pada lokasi, diikuti dengan jenis logam, kaca, kayu dan turunan, serta karet (Kahar dkk., 2020) 


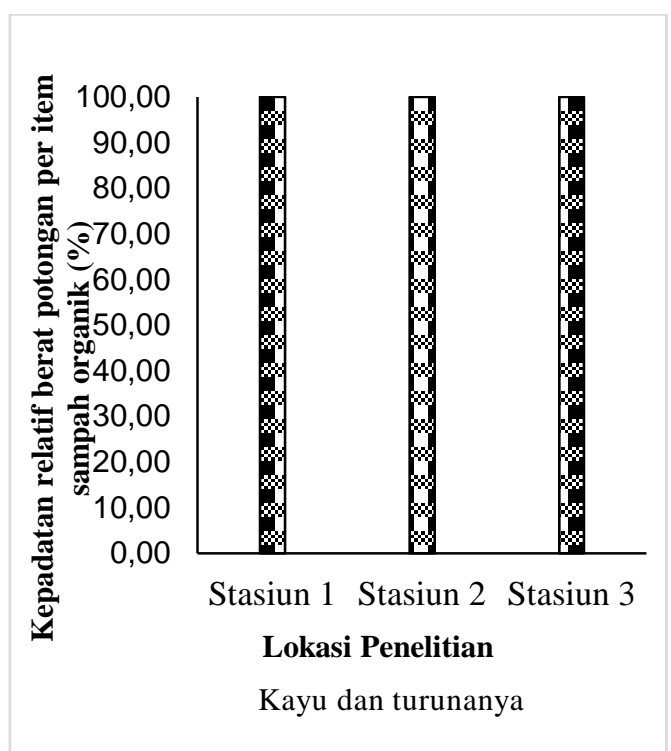

(a) Organik

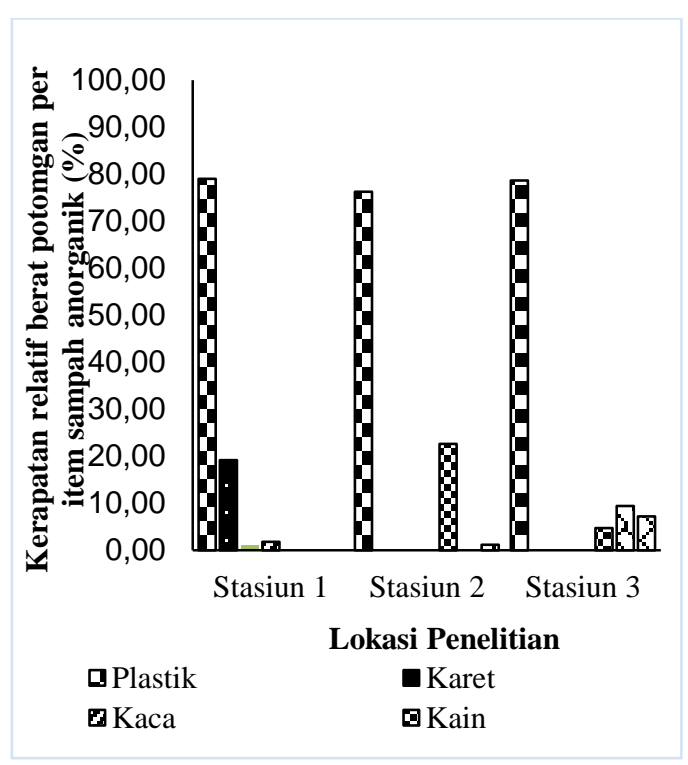

(b) anorganik

Gambar 7. Kepadatan relatif menurut berat potongan per item

Kepadatan relatif berdasarkan berat potongan per item didominasi oleh sampah organik didapatkan nilai tertinggi kayu dan turunanya $100 \%$ dan sampah anorganik didominasi oleh sampah plastik 79,05\% (Gambar 7), diduga sampah-sampah tersebut berasal dari masyarakat setempat dan aktifitas masyarakat yang berada di hulu sungai yang membuang sampah secara sembarangan. Manusia selama ini memandang sungai dan laut sebagai tempat yang cocok untuk pembuangan sampah yang merupakan hasil akhir dari aktivitas manusia itu sendiri. Karena manusia seringkali beranggapan bahwa sungai dan laut adalah tempat yang luas dan mempunyai kemampuan untuk menampung berbagai macam sampah tersebut (Wardhana, 2001).

\section{KESIMPULAN}

Sampah laut (marine debris) organik didapatkan kayu dan turunannya, sampah anorganik terdiri dari plastik, karet, kaca, logam, kain, dan lain-lainya, rata-rata potongan per item didapatkan sebanyak 27 potongan pada sampah organik, dan rata-rata berat tertinggi potongan per item didapatkan seberat $446,41 \mathrm{gr}$ sampah anorganik, kepadatan potongan per item didapatkan nilai tertinggi 0,90 item $/ \mathrm{m}^{2}$ pada sampah organik, dan kepadatan berat potongan per item dengan nilai tertinggi $14,11 \mathrm{gr} / \mathrm{m}^{2}$ sampah anorganik, kepadatan relatif potongan dan berat potongan per item dengan nilai tertinggi $100 \%$ sampah organik. 


\section{DAFTAR PUSTAKA}

Asia. dan Arifin, M. Z. 2017. Dampak Sampah Plastik Bagi Ekosistem Laut. Jurnal ilmiah. 14(1): 44-48

Assuyuti, Y. M. Zikrillah, R. B. Tanzil, M. A. Banata, A. Utami, P. 2018. Distribusi dan Jenis Sampah Laut serta Hubungannya terhadap Ekosistem Terumbu Karang Pulau Pramuka Panggang Air dan Kotok Besar di Kepulauan Seribu Jakarta. Jurnal science taific 35(2): 91 102.

Bangun, S. A. Sangari, J. R. R. Tilaar, F. F. Pratasik, S. B. Salaki, M. Pelle, W. 2019. Komposisi Sampah Laut di Pantai Tasik Ria. Kecamatan Tombariri. Kabupaten Minahasa. Jurnal IImiah Platax. $7(1): 322-328$.

[Bappeda] Badan Perencanaan Daerah. 2013. Rencana Strategis Bappeda Kota Bengkulu 2013-2018. Pemerintahan Kota Bengkulu.

[BPS] Badan Pusat Statistik Kota Bengkulu. 2019. Kota Bengkulu dalam Angka 2019. Badan Pusat Statistik. Kota Bengkulu.

Coe, J. M. Rogers, D. B. 1997. Marine Debris: Sources, Impacts, and Solutions. Spinger-Verlag New York.

Dewi, I. S. Budiarsa, A. A. Ritonga. I. R. 2015. Distribusi mikroplastik pada sedimen di Muara Badak, Kabupaten Kutai Kartanegara. Jurnal IImu Perairan, Pesisir, dan Perikanan. Universitas Syiah Kuala. 4(3) :121131.

Djaguna, A. Pelle, W. E. Schanduw, J. N. W. Hermanto, W. K. Rumampuk, N. D. C. dan Angangi, E. L. 2019. Identifikasi Sampah Laut di Pantai Tongkaina dan Talawaan Bajo. Jurnal Pesisir Laut dan Tropis. 7(3): 174-182.

Dwiyanto, B. M. 2011. Model Peningkatan Partisipasi Masyarakat dan penguatan Sinergi dalam Pengelolaan Sampah Perkotaan. Jurnal Ekonomi Pembangunan. 12(2): 239-256.

Elyazar, N. Mahendra M. S. Wardi, I. N. 2007. Dampak Aktivitas Masyarakat Terhadap Tingkat Pencemaran Air Laut di Pantai Kuta Kabupaten Badung Serta Upaya Pelestarian Lingkungan. Jurnal Ecotropik. 2(1): 1-18.

Eriksson, C. Burton H. Fitch S. Schulz M. Hoff J. V. D. 2013. Daily Accumulation Rates of Marine Debris on sub-Antarctic Island Beaches. Jurnal Marine Pollution Bulletin, 66(2): 199-208. 
Harrison, J. P. M. Sapp, M. Schratzberger and Osborn, A. M. 2011. Interactions between Microorganisms and Marine Microplastics. A Call for Fesearch. Mar. Tech. Socie. 4(5): 12-20.

Hermawan, R. 2017. Analisis Jenis Dan Bobot Sampah Laut di Pesisir Barat Pulau Selayar Sulawesi Selatan. Tesis. Bogor (ID): Institut Pertanian Bogor.

Hetherington, J. Leous, J. Anziano, J. Brockett, D. Cherson, A. Dean, E. Dillon, J. Johnson, T. Littman, M. Lukehart, N. Ombac, J. Reilly, K. 2005. The Marine Debris Research, Prevention and Reduction Act: A Policy Analysis. Columbia University New York, New York.

Hiwari, H. Purba, N. P. Insan, Y. N Yuliadi, L. P. S. Mulyan, P. G. 2019. Kondisi Sampah Mikroplastik di Permukaan Air Laut Sekitar Kupang dan Rote, Provinsi Nusa Tenggara Timur. Pros Sem Nas Masy Biodiv Indon. 5(2): 165-171.

Kahar, M. G. Joshian, N. W. Schaduw, Natalie D. C. Rumampuk, Wilmy, E. Pelle. Calvyn S. Jeannete, F. Pangemanan. 2020. Identifikasi Sampah Anorganik pada Ekosistem Mangrove Desa Talawaan Bajo Kecamatan Wori Kabupaten Minahasa Utara. Jurnal Pesisir dan Laut Tropis. 8(1): 1-6.

Lippiatt, S Ofter, S. Arthur, C. 2013. Marine Debris Monitoring and Assisment. NOAA Technical Memorandum Nos-OR dan R-462005.

Muharlis. 2014. Tinjauan Hukum Internasional Terhadap Pencemaran Lingkungan Laut Akibat Sampah di Samudra Pasifik (The Great Pasific Garbage Patch). Skripsi. Hukum Internasional Fakultas Hukum Universitas Hasanuddin. Kota Makassar.

Muti'ah. Siahan, J. dan Supriadi. 2019. Sosialisasi dan Pendampingan Masyarakat Pesisir Tentang Cara Menjaga Kebersihan Pantai dan Cara Pengukuran Jumlah Sampah. Jurnal Pendidikan dan Pengabdian Masyarakat. 2(1): 141-146.

NOAA [National Oceanic and Atmospheric Administration]. 2013. Programmatic Environmental Assessment (PEA) for the NOAA Marine Debris Program (MDP). Maryland (US): NOAA. 168.

[NOAA] National Oceanic and Atmospheric Administration. 2016. Marine Debris Impacts on Coastal and Benthic Habitats. NOAA (Marine Debris) Habitat Report. 
Nursruwening, Y. Wita, W. Wahyuningsih E. S. Pembuatan Handicraft Menggunakan Bahan Olahan Sampah Domestik. Prosiding SENATEK 2015 Fakultas Teknik. Universitas Muhammadiyah Purwokerto. Purwokerto.

Pribadi, T. D. K. Rosada, K. K. Handayani, M. F. Khairunnisa, T. S. 2017. Tingkat Pemahaman Masyarakat Tentang Sampah Laut (Marine Debris) di Sekitar Kawasan Pananjung Pangandaran. Jurnal pengabdian kepada masyarakat. 1(3): 188 - 190.

Renwarin, A. Rogi, O. A. Sela, R. L. E 2002. Studi Identifikasi Sistem Pengolahan Sampah Permukiman di Wilayah Pesisir Kota Manado. Universitas Sam Ratulangi. Menado.

Subekti, S. 2017 Pengelolaan Sampah Rumah Tangga 3R Berbasis Masyarakat. Jurnal Teknik lingkungan. 2(1) 24-30.

Tangdesu, T. R. C. 2018. Identifikasi Sampah Laut di Muara Sungai Biringkassi dan Wilayah Pesisir Sekitarnya di Kabupaten Takalar. Skripsi. Departemen IImu Kelautan. Fakultas IImu Kelautan dan Perikanan Universitas Hasanuddin. Makassar.

Taufiqurahman. 2016. Optimalisasi Pengelolaan Sampah Berdasarkan Timbulan dan Karakteristik Sampah di Kecamatan Pujon Kabupaten Malang. Skripsi. Institut Teknologi Nasional Malang. Malang.

Wardhana W. A. 2001. Dampak Pencemaran Lingkungan. Penerbit Andi. Jogyakarta.

Walalangi J. Y. 2012. Analisis Komposisi Sampah Organik dan Anorganik serta Dampak terhadap Lingkungan Pesisir Kota Palu Sulawesi Tengah. Tesis. Bogor (ID): Institut Pertanian Bogor.

Widiawati, E. Tandjaja, H. Iskandar, I. Carles, B. 2014. Kajian Potensi Pengelolaan Sampah. Jurnal Metris. 119-126.

Yunita, M. dan Edwar. 2007. Revitalisasi Objek Ekowisata Pantai Kualo Kecamatan Muara Bangkahulu Kota Bengkulu. Jurnal Georafflesia. 2(2): $76-81$.

Yogiesti, V. Hariyani, S. dan Suktikno, F. R. 2010. Pengelolaan Sampah Terpadu Berbasis Masyarakat Kota Kediri. Jurnal Tata Kota dan Daerah. 2(2): 95-102. 
E-ISSN: 2527-5186. P-ISSN: 2615-5958

Jurnal Enggano Vol. 5, No. 2, September 2020: 273-289

Zulkarnain, A. 2017. Identifikasi Sampah Laut (Marine Debris) di Pantai Bodia Kecamatan Galesong, Pantai Karama Kecamatan Galesong Utara, dan Pantai Mandi Kecamatan Galesong Selatan Kabupaten Takalar. Skripsi. Departemen IImu Kelautan. Fakultas IImu Kelautan dan perikanan Universitas Hasanuddin. Makasar. 